\title{
Marriage Formation in Context: Four Decades in Comparative Perspective
}

\author{
Claudia Geist \\ Department of Sociology, University of Utah, 380 S 1530 E RM 301, Salt Lake City, UT 84112, USA; \\ claudia.geist@soc.utah.edu; Tel.: +1-801-581-6153 \\ Academic Editor: Graham Crow \\ Received: 28 August 2016; Accepted: 11 January 2017; Published: 17 January 2017
}

\begin{abstract}
Marriage formation is deeply embedded in societal context. This study documents trends towards lower marriage rates and delayed marriage in Europe and the US. Using time series analyses, it shows the relevance of economic and gender context in understanding marriage formation. The study extends previous work by including more countries, a longer time period, and by examining changes in predictors of marriage patterns over time. Analyses show that the association between economic context and marriage rates weakens over time, but the role of gender equality and policy context remain stable. Differences in age at first marriage across policy clusters are diminishing. Although greater gender equality is consistently linked to later marriage entry, the link between economic context and age at first marriage is changing. Changes in predictors of cross-national marriage patterns over time strongly suggest the institution of marriage itself is changing.
\end{abstract}

Keywords: marriage rate; marriage age; trends; welfare state; economic context

\section{Introduction}

Many scholars and commentators have discussed the family changes that have occurred since the 1960s. In both Europe and the United States, marriage age has increased and marriage rates have fallen. Even when we set changing access to marriage for non-heterosexual couples aside, alternatives to marriage have become both less stigmatized and more common. What some call "traditional" marriage is still central to definitions of family and part of public discourse.

The interpretation of changes in marriage patterns largely depends on the underlying understanding of marriage as an individual arrangement or a heterosexual marriage to be a core societal institution [1]. Often, discussions of change are framed as marriage decline [2-4]. When seeking the underlying causes of the changes, increasing emphasis on individual autonomy and tolerance towards marriage alternatives [5] have been used as two factors to explain changing behavior at both the individual and aggregate level. There is also an extensive body of research that has studied family transitions, seeking to identify what shapes individuals' decisions to marry, have children, and separate or divorce, often focusing on their individual economic circumstances [6]. Family transitions, such as marriage formation, are deeply embedded in societal context, and the role of context remains understudied. Understanding how different contextual aspects shape marriage formation allows insights into the nature of social change underlying trends in marriage formation, and also provides a basis for speculation about the future of marriage.

Kalmijn [7] provided a very valuable study of trends in marriage, cohabitation and divorce in 37 European countries from 1990 to 2000. Differences across European countries were in part explained by differences in gender roles and religiosity. Additionally, higher levels of women's employment and high levels of unemployment were linked to lower marriage rates. Kalmijn's pioneering study covered a relatively short period (1990-2000), and as a result, most of the observed variation was 
between rather than within countries, which made identifying possible causal relationships all the more difficult.

This paper seeks to improve our understanding of how macroeconomic circumstances, gender relations, and policy regimes shape heterosexual marriage rates and timing, and how these mechanisms may have changed over time. This paper cannot fully address issues of shifting values, but instead addresses to what extent economic circumstances and other contextual factors help explain the marriage "retreat". Moreover, it specifically tests whether the effect of the economic and socio-political context on marriage formation patterns has shifted over time or whether countries' marriage patterns converge. This paper makes two key contributions. First, it maps trends in marriage formation in a broad range of advanced industrialized countries over four decades of rapid change, expanding on Kalmijn's 2007 study that covered only one decade. Since the countries share many similarities, it is all the more interesting to understand existing differences in marriage patterns. This is an essential first step for a broader assessment of both the current state and the future of marriage. Second, it systematically examines the changing relationship between economic and socio-cultural context and marriage formation patterns. It examines four decades of trends in marriage formation patterns in 22 European countries and the United States using cross-sectional time series analyses. This paper integrates the comparative welfare state approach, comparative gender inequality research, and marriage formation research. The longer time frame also allows for examination of whether the link between socio-economic context and marriage behavior has changed over time, perhaps reflecting changes in the institution of marriage. Mapping the changing impact of context on marriage rates and average age at first marriage over time provides important bridges between the literatures on political and social change, as well as family change. In the next section, I provide a brief overview of the theoretical background, followed by a brief description of measures and analytic strategy. I then turn to a presentation of results and finish with a summary and conclusions.

\section{Background}

\subsection{Marriage Formation and Economic Circumstances}

Much of the research on the association between economic circumstances and demographic trends has focused on fertility behavior [8,9].The economic foundation of marriage has been a key element of sociological research on marriage formation. Men's economic potential has been seen as a prerequisite for marriage, and unemployment as a barrier to the transition to marriage [10]. As a result, any trends undermining men's economic stability may have a negative effect on marriage transitions.

Studies showed that male employment and favorable economic circumstances uniformly increased men's likelihood of marriage [11-15]. Social change in women's economic circumstances, most prominently increased labor force participation and earnings capacity, has been linked to reduced marriage rates. There is some evidence that women's increased economic resources allowed them access to alternative life course options, including the decision not to marry [12,16-19]. Similarly, in examining both partners' economic circumstances, only men's economic circumstances seemed to affect a couple's probability of transitioning into marriage, but women's economic circumstances had no effect [14]. There is contradictory evidence that found that the lack of economic resources for both men and women reduces entry into marriage $[20,21]$. Others found rather similar associations between economic well-being and marriage entry for men and women [22,23].

One possible reason for the inconsistent findings for the association between women's economic activity and marriage at the individual level across different types of studies is that the financial autonomy that reduced women's pressure to get married was offset by women's increased financial resources, which make them more attractive partners for potential spouses [11,24-26]. 
Oppenheimer's $[13,26]$ theory of marriage timing provides a framework that argued against the idea that economic opportunities discouraged women from entering marriage. Instead, the theory suggested that modern labor markets, longer duration of education, and female labor force participation merely resulted in delayed marriage due to the increased difficulty of assortative mating and men's eroding economic positions, addressing both the micro and macro levels. Since both men's and women's marriage-related attributes (e.g., family orientation, economic potential) remain unclear until later in adulthood [22,24,27], finding a match is more difficult.

Economic up- and downturns at the societal level are associated with individuals' marriage prospects [28,29]; the economy does not only shape people's present economic circumstances, it also affects their perspective on the future and their sense of economic insecurity, such as the fear of job loss or unemployment experiences. Another example to underline the link between macro-level economic circumstances and marriage transitions is the case of political change in Germany in the 1990s. Around the time of German unification, a time of sweeping societal change, East German marriage and fertility rates went down, but both remained stable in West Germany. East Germany experienced dramatic changes in the economic context, especially the rapid rise in economic uncertainty that went beyond individuals' economic positions, which in turned seemed to (temporarily) reduce East Germans' willingness to engage in the long-term commitment associated with marriage and parenthood [30].

There is little in Oppenheimer's approach to suggest that the effects of the economic context will change over time. However, the social pressure of entering marriage is decreasing cross-nationally, in part because of the growing acceptance and prevalence of non-marital cohabitation [31]. As a result, decreasing rates of marriage and later marriage entry can become self-reinforcing, which some scholars have dubbed as a retreat from marriage. This implies that the economic context, such as unemployment rates or gross domestic product (GDP), is less and less predictive of a country's marriage patterns over time.

\subsection{Marriage Formation and Socio-Cultural and Policy Context}

Numerous studies found evidence for a subjective financial threshold to marriage. Financial and residential independence were perceived as a prerequisite for marriage, which was associated with a specific lifestyle $[21,32,33]$, and poor men and women were found to be half as likely to be married as those with incomes three times the poverty level [33]. Cohabitation may be an alternative or a bridge to marriage for those who believe that they cannot "afford" marriage [21,24,34]. Unfortunately, lack of sufficient data on cohabitation in most countries currently precludes comprehensive comparative analysis of the formation of cohabitation.

The relationship between economic circumstances and marriage formation has been widely investigated at the individual level, but it is also important to look at the aggregate level. Societal standards about financial thresholds for marriage entry imply that even if a couple did not subscribe to the ideas of economic "standards" associated with marriage, they likely faced these expectations from others in their social networks [35] and they might have "behaved" according to societal standards. The impact of economic uncertainty and economic opportunities on marriage decisions and timing transcends the individual level. Unemployment does not only affect the behavior of those who have experienced it. High unemployment rates, especially for men, may deter even those who are currently in stable employment from marrying. Similarly, women's economic independence and high levels of labor force participation may shape women's outlook on their career potential and human capital investments beyond their individual circumstances.

Of course, economic circumstances are not the only factor shaping marriage timing and marriage rates. Values and attitudes towards family and gender issues have been used as explanatory factors in the analysis of marriage transitions, mostly at the individual level. The observed increase in the proportion of women who work outside the home, for example, has been portrayed not only as a reflection of the improved opportunities for women in the workplace but also as evidence of a shift in attitudes with marriage and family taking a less central position [36]. Those with favorable attitudes 
towards marriage were found to be more likely to marry [37], and a shift in these attitudes may delay marriage and reduce marriage rates. Moreover, there is some evidence that the decrease in marriage entry may not be caused by increased societal barriers but by reduced preference for marriage [15]. However, some argue that marriage delays may be mainly due to more time spent in education [38].

Axinn and Yabiku [39] found that the role of societal (or even neighborhood) norms regarding marriage matter beyond individual-level factors [40]. Institutional features and relative importance of marriage in society, for example, may play an important role in shaping marriage formation behavior. If marriage is easily reversible, i.e., divorce is easy to achieve, then the entry barrier may not be very high, which should result in higher marriage rates and younger age at marriage. Preston and Richards [41] found that in more Catholic areas, marriage rates are lower because the high stakes associated with Catholic marriage encourage a delay in marriage.

Marriage is a gendered institution and has often been linked to more traditional patterns of behavior compared to non-marital relationships [42-44]. Ono [45] showed that gender differentiation at a societal level changed the mechanisms of marriage formation at the individual level, implying that, in the absence of gender equality, women may avoid marriage if they have the means to do so. Greater gender equality, especially concerning political power, also has the potential to increase women's independence further and result in a lower propensity for women to enter marriage or in the delay of marriage until later adulthood. This relationship needs to be examined at the macro level, and testing for possible changes over time in this relationship can be indicative of the evolution of marriage towards becoming a more egalitarian institution.

The policy context can be seen as a special case of the socio-cultural context. Some aspects of women's position in society, i.e., gender equality or the level of labor force participation, can be seen as realized policy goals [46]. In addition to the societal features discussed above, countries can be grouped into policy clusters that share similar characteristics, focusing on entire policy packages [47]. National policy context is more than the sum of economic circumstances and individual values, and shapes the relationship between states, markets, families, and individuals [47-49]. There are many possibilities to both measure and categorize policy contexts. For this study, I rely on the comparative welfare state approach $[47,48]$, which distinguishes between Social Democratic, Liberal, and Conservative regimes.

The Conservative policy framework seeks to maintain existing structures by supporting a gendered division of labor with an expansive set of social and economic policies, particularly seeking to strengthen the "traditional" family. The Liberal regime has been characterized as taking a "laissez-faire" approach with only limited state interventions in both the economic and private spheres. This is not to imply that socially liberal positions are endorsed, but rather that the importance of market relations and individualistic decision making is emphasized. There have been numerous efforts in the United States to strengthen marriage. But, marriage promotion is focused primarily on the poor population and has the goal of poverty prevention [50,51]. The Social Democratic welfare state is dedicated to equality, through the redistribution of wealth in the population but also through active efforts to reduce gender inequality and to support families through state-supported childcare. Countries are categorized based on relative consensus in the field. The Netherlands has often been considered an example of a hybrid case and has been categorized inconsistently [52]. Although some suggest the categorization as Social Democratic welfare state [53], I follow others who have treated this country as part of the Conservative cluster due to its fit with the continental European cluster [54].

More recently, scholars have suggested that these three policy types may not be enough to capture the policy circumstances in Europe. Rather than classifying the countries of Southern Europe as "weak" cases of the Conservative regime, Ferrera [55] suggests that this group of countries be treated as a cluster by itself. Whereas traditional family values are at least as central in countries like Spain, Greece, and Italy as they are in their northern counterpart countries of Esping-Andersen's Conservative policy group, the state support is a lot weaker and less generous. One of the reasons for this may be the ongoing reliance on strong family ties, which are considered as central and not in need of state support. 
The transitional economies of Eastern Europe warrant separate consideration. During the time of state socialism, the state was regulating all aspects of life in these countries. After the revolutions of 1989, the collapse of the Soviet Union in 1991, and the introduction of a largely capitalist market economy, state provision declined drastically. Although the extent of the transition to market capitalism varies in these countries, all of them share the legacy in which women used to be fully incorporated into the economy which undermines, at least ideologically, the idea of a primary male breadwinner. This legacy may also imply that men's economic circumstances are less central to marriage formation trends in these countries.

As the five policy clusters differ in the level of emphasis on traditional family arrangements and gender equality, they also differ in the level of women's labor force participation. In Conservative and Southern policy regimes, traditional employment structures are (at least indirectly) encouraged, and women's low labor force participation levels match those policies. At the other end of the spectrum, Social Democratic welfare states encourage women's equality in society and women are participating in the labor force at high levels. Liberal and Eastern regimes fall somewhere in the middle, as there are few explicit family policies, and work-family issues are left largely to market forces. Women participate in the labor force at high levels, be it out of tradition (in the Eastern policy regime), or economic necessity.

Similar to the expectation of the decreasing role of economic context outlined above, it can be expected that global trends towards gender equality and cultural change [56] will, in the long term, reduce cross-national differences, and result in a decreasing effect on the predictability of marriage entry and marriage age, particularly in the policy context. Recent trends towards fewer children and aging populations [57] also imply a pattern of partial convergence but not a lack of cross-cultural differences.

\section{Data and Methods}

I analyze marriage formation from 1961 to 2005 (the panels are unbalanced, and the number of observations varies across countries). Although the Great Recession provides an interesting example of a widespread increase in unemployment rates and economic uncertainty, the depth and extent of the economic downturn warrant separate analyses and are beyond the scope of this paper. I examine marriage rates in 23 countries, as well as average age at first marriage for women in 20 countries, as information on age at first marriage is not available for Iceland, Norway, and Switzerland. Table 1 provides information about countries and sample sizes; Table 2 provides the distributions of the included variables. Data were obtained from different sources, including Eurostat, the statistics office of the European Communities, the Organization for Economic Cooperation and Development (OECD), the United Nations Development Program, and the United States Center for Disease Control and Prevention. 
Table 1. Countries and Policy Clusters.

\begin{tabular}{|c|c|c|c|}
\hline Policy Cluster & Country & \multicolumn{2}{|c|}{ Year Range } \\
\hline \multirow{3}{*}{ Liberal $\mathrm{N}=100$} & Ireland & 1967 & 2005 \\
\hline & United Kingdom & 1963 & 2005 \\
\hline & United States & 1963 & 2004 \\
\hline \multirow{7}{*}{ Conservative $\mathrm{N}=251$} & Austria & 1969 & 2005 \\
\hline & Belgium & 1963 & 2000 \\
\hline & France & 1963 & 2005 \\
\hline & Germany & 1961 & 2005 \\
\hline & Luxembourg & 1975 & 2005 \\
\hline & Netherlands & 1976 & 2003 \\
\hline & Switzerland * & 1976 & 2005 \\
\hline \multirow{5}{*}{ Social Democratic N = 181} & Denmark & 1961 & 2005 \\
\hline & Finland & 1963 & 2005 \\
\hline & Iceland * & 1992 & 2005 \\
\hline & Norway * & 1961 & 2005 \\
\hline & Sweden & 1964 & 2005 \\
\hline \multirow{4}{*}{ Southern $\mathrm{N}=123$} & Greece & 1978 & 2004 \\
\hline & Italy & 1963 & 2005 \\
\hline & Portugal & 1981 & 2005 \\
\hline & Spain & 1971 & 2005 \\
\hline \multirow{4}{*}{ Eastern $\mathrm{N}=52$} & Czech Republic & 1991 & 2005 \\
\hline & Hungary & 1993 & 2005 \\
\hline & Poland & 1993 & 2005 \\
\hline & Slovakia & 1995 & 2005 \\
\hline
\end{tabular}

Note: ${ }^{*}$ indicates countries for which information is available on marriage rates, but not average age at first marriage.

Table 2. Summary Statistics $\left(\mathrm{N}=707\right.$ country years $\left.^{1}\right)$.

\begin{tabular}{cccccl}
\hline & Mean & Std. Dev. & Min. & Max. & \multicolumn{1}{c}{ Description } \\
\hline Crude Marriage Rate & 6.16 & 1.42 & 3.57 & 12.82 & Number of marriages/1000 population \\
\hline Average Age at First Marriage & 25.43 & 2.02 & 21.40 & 31.52 & Women's mean age at first marriage \\
\hline Male Unemployment Rate & 5.51 & 3.97 & 0.10 & 20.10 & $\begin{array}{l}\text { Percentage of those in civil employment } \\
\text { who are unemployed }\end{array}$ \\
\hline Female Labor Force Participation & 56.73 & 12.98 & 29.00 & 85.70 & $\begin{array}{l}\text { Percentage of women between the ages of } \\
15 \text { to 64 who are employed }\end{array}$ \\
\hline GDP & 14.60 & 9.75 & 1.58 & 63.45 & $\begin{array}{l}\text { Gross domestic product per capita (based } \\
\text { on US dollar purchasing power parity) }\end{array}$ \\
\hline Divorce Rate & 1.74 & 1.03 & 0.00 & 5.30 & \begin{tabular}{l} 
Number of divorces/1000 population \\
\hline Gender Equality
\end{tabular} \\
& 0.103 & 0.81 & -1.38 & 1.35 & $\begin{array}{l}\text { Average of standardized Gender-Related } \\
\text { Development Index/Human Development } \\
\text { Index and Gender Empowerment Measure } \\
\text { both measures standardized; higher values } \\
\text { indicate greater equality) }\end{array}$ \\
\hline
\end{tabular}

Note: ${ }^{1}$ For the analyses of age at first marriage the number of observations is 511.

\subsection{Measures}

\subsubsection{Marriage Measures}

I examine two different marriage measures: marriage rates and age at first marriage. Marriage rates are crude marriage rates, which are the number of marriages per 1000 population. Age at first marriage is the average age at first marriage for women. 


\subsubsection{Economic Context Measures}

I examine the effect of male unemployment rates to test whether a possible erosion of male economic security undermines nuptiality. Male unemployment is measured as the percentage of men unemployed among the civilian labor force. The civilian labor force excludes institutionalized populations (i.e., those in hospitals or prisons) and those who are in the military; this measure is based on OECD data. I further include a measure of female labor force participation to assess how women's overall economic independence affects marriage rates. Female labor force participation is measured as the percentage of women between the ages of 15 to 64 who are employed. The level of female labor force participation can also be interpreted as a measure of women's economic opportunity since it provides insights into the relative difficulty or ease of women entering paid work. I also include the GDP per capita, with US dollar purchasing power parity, provided by the OECD, which captures the economic outlook for the population in general.

\subsubsection{Socio-Cultural Context Measures}

The family and gender related aspects of context are measured by two different measures. First, crude divorce rates (the number of divorces per 1000 population) represent the relative ease (or difficulty) with which individuals can exit a marriage, and are consequently a reflection of how protected the institution of marriage is. Measures of ease of marriage entry and measures of the cultural centrality of marriage are not readily available. Second, the gender equality measure is based on the average of two frequently used measures of women's position in society.

The first component of the gender equality measure is the ratio of the gender-related development index (GDI) and human development index (HDI). Using the GDI by itself is not a measure of gender inequality, since gender inequality becomes apparent only by comparing the unadjusted HDI with the gender adjusted GDI. Both are composite indices that combine life expectancy, education (adult literacy and enrolment in different levels of education), and estimated earned income per capita. The gender-related development index adjusts the HDI to reflect inequalities between men and women in these three dimensions. The creators of these measures suggest that the ratio of both measures is an approximate, yet imperfect, measure of gender inequality in a society [58]. I use the inverted ratio, so higher values indicate greater equality.

The second component of the gender equality measure is the Gender Empowerment Measure (GEM), which reflects women's relative power in society. It is a composite that reflects gender inequality in parliamentary representation, economic participation (the index includes gender inequality in the positions of legislators, senior officials, and managers, as well as women's representation in professional and technical positions), and women's power over economic resources, the latter being measured by comparing female and male estimated earned income. Unfortunately, these measures were only collected from 1995 onwards. As a consequence, I create a time invariant average for each of the countries by creating the average of the first available measure and the measure from 2006 for the GDI/HDI ratio and the GEM. Since the GDI/HDI ratio and the GEM tap into slightly different but related aspects of gender equality and are scaled differently, I standardize both measures before they are averaged for my overall equality measure. Again, higher values indicate greater equality. For Germany, the earliest GEM available is from 1996, and for Iceland, the Czech Republic and Slovakia the earliest are from 1998. GEM 2006 is not available for Luxembourg and France. Instead, I used data from 2007 (France) and 1999 (Luxembourg). It would be preferable to have measures of gender empowerment and gender inequality prior to 1995 but I find that between 1995 and 2006, the relative order of countries with respect for gender empowerment has changed little: nine out of the ten countries with the highest level of gender empowerment in 1995 are still counted among the top 10 in 2006. Although there has been a change in the GDI/HDI ratio, the relative position of countries with respect to gender equality has remained relatively stable. 


\subsubsection{Policy Context Measures}

I include a measure of policy regime, which categorizes the sample countries into five policy groups. I distinguish between Liberal, Conservative, Social Democratic, Southern, and Eastern countries (see Table 1). I also allow for trends over time, by including an indicator for year. The countries considered in the analyses have different population structures, which could pose a problem given the fact that I am examining crude marriage rates. In supplemental analyses, I included the proportion of individuals 65 years or older. This indicator is significantly associated with lower rates of marriage but does not systematically affect the other findings. The present paper will not explore the independent effect of population structure in more detail as the population age is linked in complex ways to not just marriage patterns but also to the welfare state/policy context. I explore these issues in a separate study. In the examination of change in the association between context and marriage patterns over time, I create interaction effects with the aforementioned contextual factors and time in years. For detailed distributions for the measures used in this paper see Table 2.

\subsection{Analytic Strategy}

I proceed in three analytic steps. I first show average marriage rates and age at first marriage for all countries and document how marriage rates and age at first marriage have changed over time. In a second step, I use multivariate regressions to examine the extent to which economic and socio-political context matter for trends in marriage formation. In a third step, I illustrate how the association between economic context and marriage timing varies over time.

The multivariate analyses rely on time-series-cross-sectional feasible generalized least square (FGLS) models with panel corrected standard errors and first-order autocorrelation (see Beck and Katz [59] for a discussion about model selection for panel data). Standard errors are panel corrected (PCSE), adjusting for the contemporaneous correlation of the errors among countries. Although point estimates from ordinary least square OLS regressions would be unbiased, they are inefficient. This panel correction accounts for the panel structure of the data, but not serial dependency. Because the observations are repeated over time, the errors will be serially autocorrelated. A common solution to the serial autocorrelation problem is to employ a first-order autocorrelation (AR(1) correction) to the observations, relying on a Prais-Winsten transformation so as to not lose the information from the first observation which does not have an antecedent [60,61]. In this paper, I use panel specific AR1 corrections, since it is unlikely for autocorrelation patterns to be identical across all countries. In the resulting FGLS models, the time-variant independent variables are lagged; economic context measures are lagged by one year since it can be assumed that the link between economic circumstances and marriage behavior is rather direct. For the divorce rates, the one time-variant measure of socio-cultural context is lagged by three years, reflecting the slower response of an individual's marriage behavior to changing cultural context.

\section{Results}

Figure 1 presents trends in marriage by country over time. Figure 1a illustrates both the average marriage rate each year for all countries combined (in bold), as well as the trends in marriage rates for each country. Figure $1 \mathrm{~b}$ shows the trends in average age at first marriage.

Figure 1 illustrates that in all countries marriage rates have dropped by a small to moderate amount over the recent decades, yet there is no drastic decline. In most countries, marriage rates peaked in the late 1960s to early 1970s and declined somewhat more steeply after that. In the 1990s, marriage rates seem to stabilize for the majority of countries, and even increase for some countries.

The two spikes observed in the late 1980s are Austria (1987) and Sweden (1989), where policy changes resulted in unique incentives to be married that year. In Austria, newlyweds used to receive a government grant, but this policy was discontinued in 1988. The increase in marriage rates in 1987 in Austria can easily be interpreted as a direct reaction to the anticipated policy change [62]. In Sweden, 
the drastic changes in survivor benefits that would result in more generous benefits for those married by a certain date (among other conditions) sparked a dramatic rise in marriage in a country with otherwise very low marriage rates [63]. Both of these examples show that marriage behavior responds to policies that shape the attractiveness of marriage.

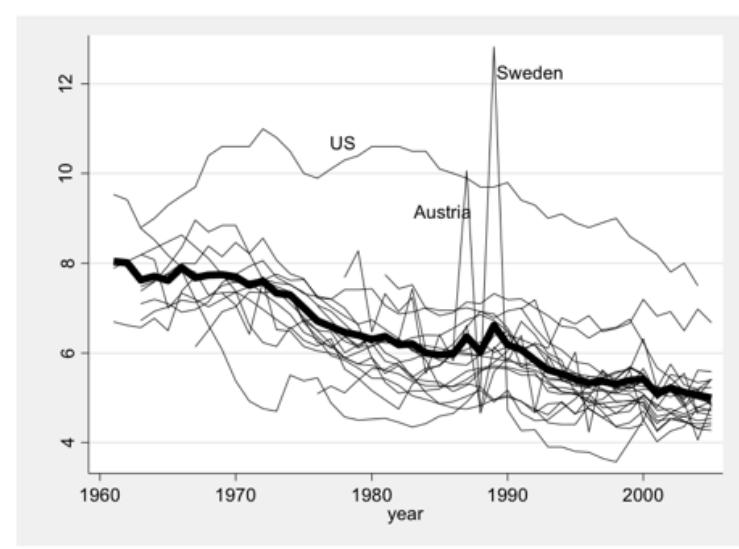

(a)

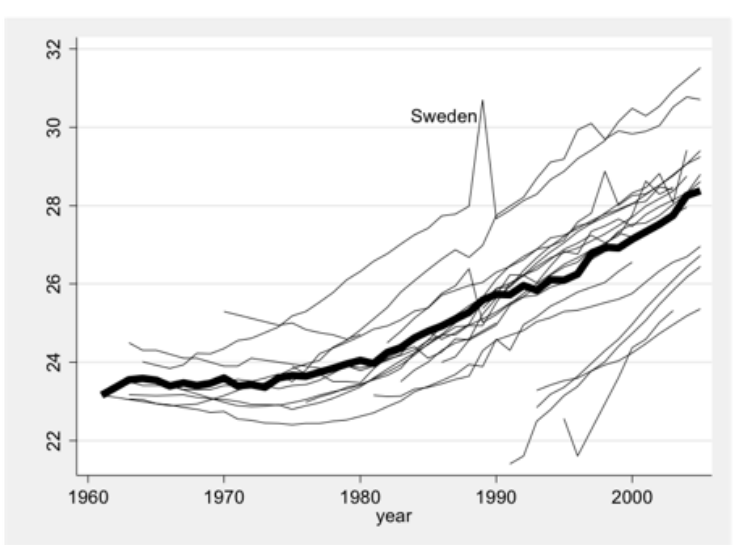

(b)

Figure 1. Trends in Marriage Rates and Average Age at First Marriage, 1961-2005. (a) Marriage Rates; (b) Marriage Age.

The second panel in Figure 1 shows that while marriage rates have declined, marriage age has increased; in 1960, the average age at first marriage for women was around 23 years, with relatively little variation across nations. Over time, it has increased to an average age of about 28 years, with greater variation across countries. In the 1960s the standard deviation in women's average age at first marriage across all countries was about 0.5 years, compared to a standard deviation of more than 1.7 years in the most recent years of data. Again, the spike that can be seen in 1989 is the average age at first marriage in Sweden, at the same time when that country also saw a phenomenal increase in marriage rates due to a limited time marriage incentive. There is no comparable spike for Austria, which suggests that those who married in the peak year were not dramatically different from those who entered marriage in other years. In Sweden, however, it seems that the change in pension laws motivated a very different group of Swedes to marry; presumably those who were older and were living with their partners without the intent of getting married were it not for the financial incentive of the policy change. In the remainder of the paper, I show results from multivariate regressions. It is important to keep in mind that these results present important multivariate descriptive evidence, but they do not provide causal explanations.

In Table 3, I examine the impact of economic context, socio-cultural context, and policy context. I find that the role of economic context is substantial: there is a negative association between male unemployment and marriage rates. Taken apart from other contextual dimensions, a higher level of gender equality is associated with higher marriage rates. The distinction between the policy regimes is pronounced: looked at apart from other factors, Social Democratic countries have significantly lower marriage rates than all other policy clusters.

For age at first marriage, I find a positive association between male unemployment as well as GDP and delayed marriage. Higher levels of female labor force participation are negatively linked to age at first marriage (even when the US is excluded). Both higher divorce rates, a possible measure for ease of marriage exit, and higher scores on the gender equality index are associated with lower age at first marriage. Just as with the findings for marriage rates, the differences between the policy clusters are substantial: the age at marriage is highest in Social Democratic countries compared to all other policy clusters except the Liberal countries. Excluding the US observations does not significantly alter the results for either marriage rates or marriage timing. The effect sizes become smaller, but the overall 
direction of the effects is the same. As expected, marriage rates decline and age at first marriage rises over time.

Table 3. Panel Corrected Prais-Winsten Models for Marriage Rates and Age at First Marriage.

\begin{tabular}{lcc}
\hline \multicolumn{1}{l}{ Crude Marriage Rates } & Age at First Marriage \\
\hline Economic Context & & \\
\hline Male Unemployment Rate & $-0.037^{* * *}$ & $0.019^{*}$ \\
& $(0.011)$ & $(0.010)$ \\
\hline \multirow{2}{*}{ Female Labor Force Participation } & 0.002 & $-0.019^{*}$ \\
& $(0.008)$ & $(0.008)$ \\
GDP & 0.014 & $0.0300^{*}$ \\
& $(0.014)$ & $(0.012)$ \\
\hline Socio-cultural Context & & $-0.136^{* *}$ \\
Crude Divorce Rate & 0.079 & $(0.050)$ \\
\hline \multirow{2}{*}{ Gender Equality } & $(0.061)$ & $-0.323^{+}$ \\
& $0.541^{* *}$ & $(0.169)$ \\
\hline Policy Context & $(0.149)$ & -0.470 \\
\hline \multirow{2}{*}{ Liberal } & & $(0.421)$ \\
\hline Conservative & $1.830^{* *}$ & $-1.420^{* *}$ \\
& $(0.385)$ & $(0.289)$ \\
\hline
\end{tabular}

Social Democratic (Ref.)

\begin{tabular}{lcc}
\hline \multirow{2}{*}{ Southern } & $2.053^{* *}$ & $-2.036^{* *}$ \\
& $(0.425)$ & $(0.398)$ \\
\hline \multirow{2}{*}{ Eastern } & $0.784^{*}$ & $-3.468^{* *}$ \\
& $(0.368)$ & $(0.457)$ \\
\hline \multirow{2}{*}{ Year } & $-0.0671^{* *}$ & $0.091^{* *}$ \\
& $(0.014)$ & $(0.016)$ \\
\multirow{2}{*}{ Constant } & $-10.040^{+}$ & $31.750^{* *}$ \\
& $(6.091)$ & $(7.010)$ \\
\hline
\end{tabular}

Note: Crude divorce rate is lagged by three years, the economic indicators (male unemployment rate, female labor force participation, and GDP), are lagged by one year. These models include a dummy indicator for the peak year in Sweden and Austria. Models also include controls for the proportion of the population in the age groups $0-15,15-19,20-24,25-29,30-34,35-39,40-49,50-59$, and 60-69. Numbers in parentheses are z-statistics. $+p<0.1 ;{ }^{*} p<0.05 ;{ }^{* *} p<0.01$.

In a second analytic step, I examine whether there is evidence that associations between the three contextual dimensions and marriage formation change over time. I find some evidence that contextual effects attenuate over time. Table 4 illustrates that, in line with expectations, the negative association between male unemployment and marriage rates is weakening over time, as indicated by a positive interaction with time. The association with GDP is no longer significant once its impact is allowed to vary over time. The differences in marriage rates across different policy regimes and the positive link between gender equality and marriage rates, however, are stable over time, contrary to expectations for cross-national convergence and a corresponding weakening of contextual effects. 
Table 4. Panel Corrected Prais-Winsten Models for Marriage Rates and Age at First Marriage with Trends over Time.

\begin{tabular}{|c|c|c|}
\hline & Crude Marriage Rates & Age at First Marriage \\
\hline \multicolumn{3}{|l|}{ Economic Context } \\
\hline Male Unemployment Rate & $\begin{array}{c}-0.092 \text { ** } \\
(0.034)\end{array}$ & $\begin{array}{c}-0.059^{+} \\
(0.031)\end{array}$ \\
\hline Male Unemployment Rate ${ }^{*}$ Time & $\begin{array}{l}0.002^{+} \\
(0.001)\end{array}$ & $\begin{array}{l}0.002 * \\
(0.001)\end{array}$ \\
\hline Female Labor Force Participation & $\begin{array}{l}-0.024 \\
(0.017) \\
\end{array}$ & $\begin{array}{c}0.016 \\
(0.020)\end{array}$ \\
\hline Female Labor Force Participation * Time & $\begin{array}{c}0.001 \\
(0.001)\end{array}$ & $\begin{array}{c}-0.001 \\
(0.001)\end{array}$ \\
\hline GDP & $\begin{array}{c}-0.008 \\
(0.049) \\
\end{array}$ & $\begin{array}{c}-0.186^{* *} \\
(0.041) \\
\end{array}$ \\
\hline GDP * Time & $\begin{array}{l}<0.001 \\
(0.001)\end{array}$ & $\begin{array}{c}0.005^{* *} \\
(0.001)\end{array}$ \\
\hline \multicolumn{3}{|l|}{ Socio-cultural Context } \\
\hline Crude Divorce Rate & $\begin{array}{l}0.398 * \\
(0.173)\end{array}$ & $\begin{array}{c}-0.435^{* *} \\
(0.144)\end{array}$ \\
\hline Crude Divorce Rate ${ }^{*}$ Time & $\begin{array}{c}-0.008 \\
(0.005)\end{array}$ & $\begin{array}{c}0.013 \text { ** } \\
(0.004)\end{array}$ \\
\hline Gender Equality & $\begin{array}{c}0.321 \\
(0.278)\end{array}$ & $\begin{array}{c}-0.053 \\
(0.357)\end{array}$ \\
\hline Gender Equality * Time & $\begin{array}{c}0.005 \\
(0.00894)\end{array}$ & $\begin{array}{c}-0.005 \\
(0.0104)\end{array}$ \\
\hline \multicolumn{3}{|l|}{ Policy Context } \\
\hline Liberal & $\begin{array}{l}1.973 * * \\
(0.591)\end{array}$ & $\begin{array}{c}1.345 \\
(0.884) \\
\end{array}$ \\
\hline Liberal * Time & $\begin{array}{c}-0.006 \\
(0.021)\end{array}$ & $\begin{array}{c}-0.105^{* *} \\
(0.028)\end{array}$ \\
\hline Conservative & $\begin{array}{l}0.956^{*} \\
(0.396)\end{array}$ & $\begin{array}{c}-0.700^{+} \\
(0.413)\end{array}$ \\
\hline Conservative ${ }^{*}$ Time & $\begin{array}{l}-0.008 \\
(0.015)\end{array}$ & $\begin{array}{c}-0.051 \text { ** } \\
(0.013)\end{array}$ \\
\hline Social Democratic (Ref.) & - & - \\
\hline Social Democratic * Time (=Overall Time Trend) & $\begin{array}{c}-0.101 \text { ** } \\
(0.036)\end{array}$ & $\begin{array}{c}0.122 * * \\
(0.039)\end{array}$ \\
\hline Southern & $\begin{array}{c}1.895 * * \\
(0.603)\end{array}$ & $\begin{array}{c}0.809 \\
(0.664)\end{array}$ \\
\hline Southern * Time & $\begin{array}{l}<0.001 \\
(0.023)\end{array}$ & $\begin{array}{c}-0.108^{* *} \\
(0.021)\end{array}$ \\
\hline Eastern & $\begin{array}{c}2.533 \\
(1.579)\end{array}$ & $\begin{array}{c}-5.575^{* *} \\
(1.019)\end{array}$ \\
\hline Eastern * Time & $\begin{array}{l}-0.051 \\
(0.043)\end{array}$ & $\begin{array}{c}0.020 \\
(0.029)\end{array}$ \\
\hline
\end{tabular}

Note: Crude divorce rate is lagged by three years, the economic indicators (male unemployment rate, female labor force participation, and GDP), are lagged by one year. These models include a dummy indicator for the peak year in Sweden and Austria. Models also include controls for the proportion of the population in the age groups $0-15,15-19,20-24,25-29,30-34,35-39,40-49,50-59$, and 60-69. Numbers in parentheses are z-statistics, ${ }^{+} p<0.1 ;{ }^{*} p<0.05 ;{ }^{* *} p<0.01$. 
The results for age at first marriage are more complex. I find that the effect of male unemployment is significant and negative once it is allowed to change over time and that the direction of the association between marriage age and the main effect of GDP is negative, once it also is allowed to vary over time. This is in contrast to findings presented in Table 3 and will be further explored below. Similar to results presented in Table 3, higher divorce rates are associated with earlier marriage, but this effect is rapidly diminishing over time. Once allowed to vary over time, gender equality no longer has a significant effect. Moreover, the results in Table 4 suggest that the differences in age at first marriage across policy clusters vary over time. The nature of this change will be explored below. In a final step, I illustrate the effects of GDP and welfare state context on marriage timing to better understand the change over time.

Figure 2 illustrates the changing effect of a one unit change in GDP on age at first marriage for each year. Higher levels of economic prosperity are associated with earlier marriage until 1990 and are not statistically significant from 1991 to 2001. In the most recent years, higher levels of GDP are associated with later marriage.

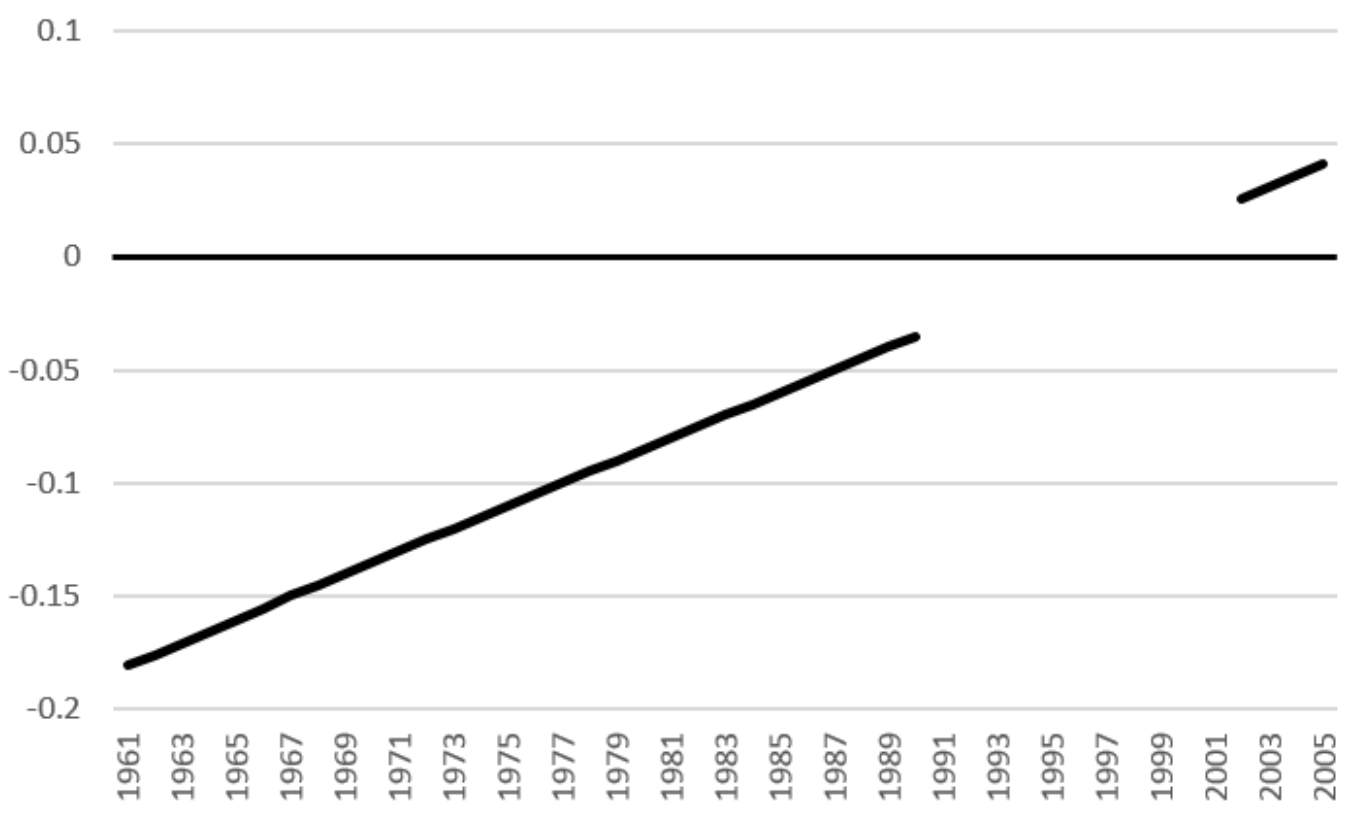

Figure 2. Change in the Association between GDP and Average Age at First Marriage (Effect of 1-unit change is shown). Note: Any non-linearity is due to rounding errors. Only effects that are significant at the 0.05 level are displayed.

In keeping with the results from the tables, the Social Democratic policy cluster is used as the reference category in Figure 3. The difference between Social Democratic and Conservative countries is slightly increasing and significant from 1961 through 2005. The differences between Social Democratic countries and Southern and Liberal countries respectively were not significant from the 1960s until the mid (Southern countries) to late (Liberal countries) 1970s, although they have been increasing since. This suggests at least partial divergence in age at first marriage. In contrast, the large difference in age at first marriage between Social Democratic countries and Eastern European countries has been slightly decreasing over the decades examined here. 


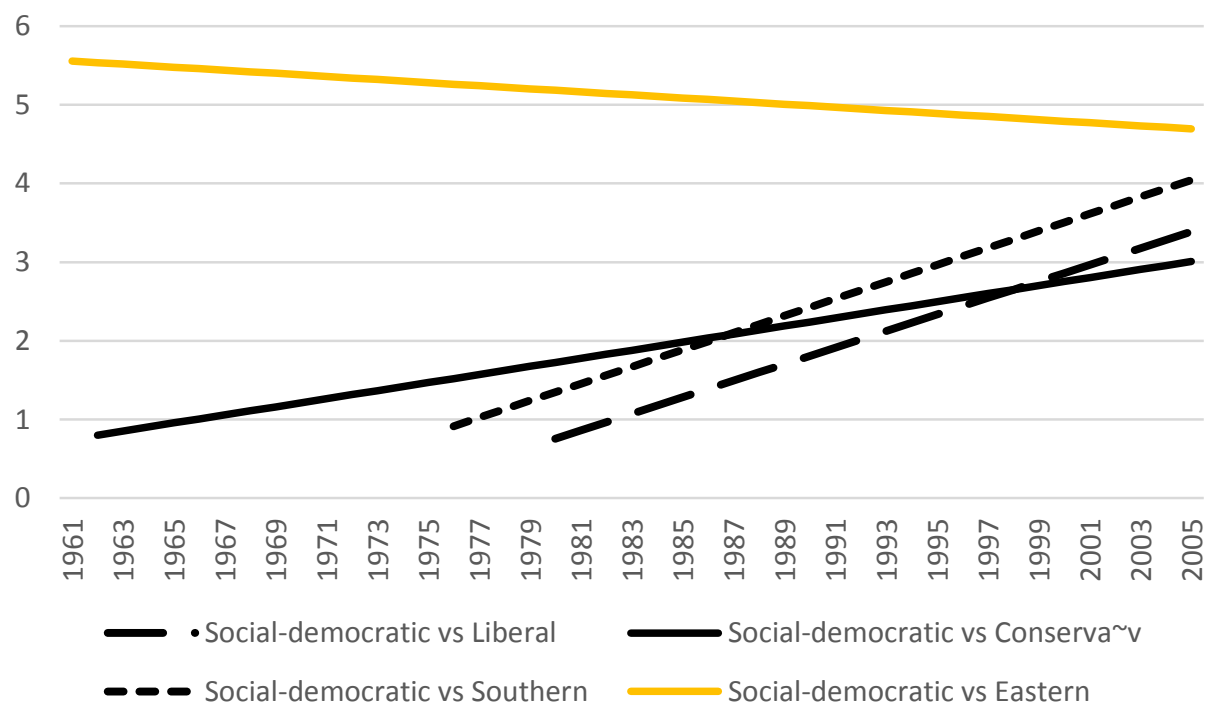

Figure 3. Change in the Difference between Policy Clusters in Average Age at First Marriage. Note: Any non-linearity is due to rounding errors. Only effects that are significant at the 0.05 level are displayed.

\section{Discussion}

In this paper, I document marriage rates and age at first marriage for 23 countries spanning roughly the last four decades of the 20th century. I show that there is a trend towards lower marriage rates and delayed first marriage age in Europe and the United States. Using multivariate time-series analyses, I find that marriage formation is sensitive to variation in economic as well as cultural and policy context, even when detailed population composition is taken into account. Policy differences in rates and marriage timing go beyond differences in economic and gender equality structures.

The nature of the link between economic context and age at first marriage is changing. These findings are in line with Oppenheimer's theory of marriage timing, with economic change resulting in longer searches. Higher GDP in more recent years can be seen as an indicator of the "modern" labor market structure which, according to Oppenheimer, is linked to later marriage. The finding that male unemployment is increasingly associated with marriage delays provides empirical support for the notion that men's economic instability may be a key source of slowed transitions into marriage in more recent times.

The effect of socio-cultural and policy context on marriage rates is stable, suggesting that there are persistent cross-national differences in the rates of marriage driven by policy circumstances, perhaps due to variations in policy incentives to marry or other institutional structures that foster alternatives to marriage. For age at first marriage, the discrepancies between policy clusters are mostly diminishing over time. One possible explanation for diminishing differences across welfare states is the trend towards prolonged educational careers and later entry into stable careers, as suggested by Oppenheimer. Due to the increased globalization of labor market and isomorphism in education structures, these factors matter regardless of policy regime.

Although the paper accounts for detailed population age structures, alternative measures of marriage formation should be explored in future research as they become available. Despite the limitations in the measure of marriage rates, this study speaks to the larger debate about the future of the institution of marriage.

\section{Conclusions}

As economic context loses predictive power for marriage rates, the finding that in recent years both male unemployment and higher GDP are associated with marriage delays, suggests that those concerned with a further increase in marriage age (and subsequent lower marital fertility potential) do 
not have a clear-cut avenue to achieve this goal, as both the lack of economic stability and greater overall prosperity are linked to delays. Economic context aside, policy clusters matter for understanding marriage formation, and additional research is needed on how specific policies shape marriage rates and timing.

Acknowledgments: This study was supported in part by a National Science Foundation Doctoral Dissertation Research Improvement Award (SOC-DDRI 0525873).

Conflicts of Interest: The author declares no conflict of interest. The founding sponsors had no role in the design of the study; in the collection, analyses, or interpretation of data; in the writing of the manuscript, and in the decision to publish the results.

\section{References}

1. Amato, Paul R. "Tension between institutional and individual views of marriage." Journal of Marriage and Family 66 (2004): 959-65. [CrossRef]

2. Ruggles, Steven. "Marriage, family systems, and economic opportunity in the USA since 1850." Gender and Couple Relationships 6 (2016): 3-41.

3. Schoen, Robert. "The continuing retreat of marriage: Figures from marital status life tables for United States females, 2000-2005 and 2005-2010." In Dynamic Demographic Analysis. Edited by Robert Schoen. New York: Springer, 2016, pp. 203-15.

4. Lundberg, Shelly, and Robert A. Pollak. “The evolving role of marriage: 1950-2010." Future Child 25 (2015): 29-50. [CrossRef]

5. Thornton, Arland, and Linda Young-DeMarco. "Four decades of trends in attitudes toward family issues in the United States: The 1960s through the 1990s." Journal of Marriage and Family 63 (2001): 1009-37. [CrossRef]

6. Blossfeld, Hans-Peter, and Johannes Huinink. "Human capital investments or norms of role transition? How women's schooling and career affect the process of family formation." American Journal of Sociology 97 (1991): 143-68. [CrossRef]

7. Kalmijn, Matthijs. "Explaining cross-national differences in marriage, cohabitation, and divorce in Europe, 1990-2000." Population Studies 61 (2007): 243-63. [CrossRef] [PubMed]

8. Goldstein, Joshua, Michaela Kreyenfeld, Aiva Jasilioniene, and Deniz D. K. Örsal. "Fertility reactions to the ‘Great Recession' in Europe: Recent evidence from order-specific data." Demographic Research 29 (2013): 85-104. [CrossRef]

9. Kreyenfeld, Michaela, Gunnar Andersson, and Ariane Pailhé. "Economic uncertainty and family dynamics in Europe: Introduction." Demographic Research 27 (2012): 835-52. [CrossRef]

10. South, Scott J., and Kim M. Lloyd. "Marriage opportunities and family formation: Further implications of imbalanced sex ratios." Journal of Marriage and Family 54 (1992): 440-51. [CrossRef]

11. Lichter, Daniel T., Diane K. McLaughlin, George Kephart, and David J. Landry. "Race and the retreat from marriage: A shortage of marriageable men?" American Sociological Review 57 (1992): 781-99. [CrossRef]

12. Lichter, Daniel T., Felicia B. LeClere, and Diane K. McLaughlin. "Local marriage markets and the marital behavior of black and white women." American Journal of Sociology 96 (1991): 843-67. [CrossRef]

13. Oppenheimer, Valerie K. "Women's rising employment and the future of the family in industrial societies." Population and Development Review 20 (1994): 293-342. [CrossRef]

14. Smock, Pamela J., and Wendy D. Manning. "Cohabiting partners' economic circumstances and marriage." Demography 34 (1997): 331-41. [CrossRef] [PubMed]

15. Speare, Alden, Jr., and Frances K. Goldscheider. "Effects of marital status change on residential mobility." Journal of Marriage and Family 49 (1987): 455-64. [CrossRef]

16. Cherlin, Andrew. "Recent changes in American fertility, marriage, and divorce." The Annals of the American Academy of Political and Social Science 510 (1990): 145-54. [CrossRef]

17. Ermisch, John F. "Economic opportunities, marriage squeezes and the propensity to marry: An economic analysis of period marriage rates in England and Wales." Population Studies 35 (1981): 347-56. [CrossRef]

18. Moffitt, Robert. The Effect of Welfare on Marriage and Fertility. Washington: National Academy Press, 1998.

19. White, Lynn K. "A note on racial differences in the effecty of female economic opportunity on marriage rates." Demography 18 (1981): 349-54. [CrossRef] [PubMed] 
20. Smock, Pamela J. “The wax and wane of marriage: Prospects for marriage in the 21st century." Journal of Marriage and Family 66 (2004): 966-73. [CrossRef]

21. Smock, Pamela J., Wendy D. Manning, and Meredith Porter. "'Everything's there except money': How money shapes decisions to marry among cohabitors." Journal of Marriage and Family 67 (2005): 680-96. [CrossRef]

22. Sweeney, Megan M. "Two decades of family change: The shifting economic foundations of marriage." American Sociology Review 67 (2002): 132-47. [CrossRef]

23. White, Lynn, and Stacy J. Rogers. "Economic circumstances and family outcomes: A review of the 1990s." Journal of Marriage and Family 62 (2000): 1035-51. [CrossRef]

24. Clarkberg, Marin. "The price of partnering: The role of economic well-being in young adults' first union experiences." Social Forces 77 (1999): 945-68. [CrossRef]

25. Goldstein, Joshua R., and Catherine T. Kenney. "Marriage delayed or marriage forgone? New cohort forecasts of first marriage for US women." American Sociology Review 66 (2001): 506-19. [CrossRef]

26. Oppenheimer, Valerie K. "Women's employment and the gain to marriage: The specialization and trading model." Annual Review of Sociology 23 (1997): 431-53. [CrossRef] [PubMed]

27. Oppenheimer, Valerie K. “A theory of marriage timing." American Journal of Sociology 94 (1988): 563-91. [CrossRef]

28. Basavarajappa, Katya G. “The influence of fluctuations in economic conditions on fertility and marriage rates, Australia, 1920-21 to 1937-38 and 1946-47 to 1966-67." Population Studies 25 (1971): 39-53. [CrossRef] [PubMed]

29. South, Scott J., and Katherine Trent. "Sex ratios and women's roles: A cross-national analysis." American Journal Sociology 93 (1988): 1096-115. [CrossRef]

30. Adler, Marina A. "Social change and declines in marriage and fertility in Eastern Germany." Journal of Marriage and Family 59 (1997): 37-49. [CrossRef]

31. Hiekel, Nicole, Aart C. Liefbroer, and Anne-Rigt Poortman. "Understanding diversity in the meaning of cohabitation across Europe." European Journal of Population 30 (2014): 391-410. [CrossRef]

32. Dixon, Rut B. "Explaining cross-cultural variations in age at marriage and proportions never marrying." Population Studies 25 (1971): 215-33. [CrossRef] [PubMed]

33. Gibson-Davis, Christina M., Kathryn Edin, and Sara McLanahan. "High hopes but even higher expectations: The retreat from marriage among low-income couples." Journal of Marriage and Family 67 (2005): 1301-12. [CrossRef]

34. Edin, Kathryn, and Joanna M. Reed. "Why don't they just get married? Barriers to marriage among the disadvantaged." The Future of Children (2005): 117-37. [CrossRef]

35. Seltzer, Judith A. "Families formed outside of marriage." Journal of Marriage and Family 62 (2000): 1247-68. [CrossRef]

36. Preston, Samuel H. "Comment on Steven Ruggles's 'The rise of divorce and separation in the United States, 1880-1990'." Demography 34 (1997): 473-74. [CrossRef]

37. Sassler, Sharon, and Robert Schoen. "The effect of attitudes and economic activity on marriage." Journal of Marriage and Family 61 (1999): 147-59. [CrossRef]

38. Barber, Jennifer S., and William G. Axinn. "The impact of parental pressure for grandchildren on young people's entry into cohabitation and marriage." Population Studies 52 (1998): 129-44. [CrossRef]

39. Axinn, William G., and Scott T. Yabiku. "Social change, the social organization of families, and fertility limitation." American Journal of Sociology 106 (2001): 1219-61. [CrossRef]

40. Mosher, W., Jo Jones, and Joyce C. Abma. "Intended and unintended births in the United States: 1982-2010." National Health Statistics Reports 55 (2012): 1-28.

41. Preston, Samual H., and Alan T. Richards. "The influence of women's work opportunities on marriage rates." Demography 12 (1975): 209-22. [CrossRef] [PubMed]

42. Baxter, Janeen, Belinda Hewitt, and Michele Haynes. "Life course transitions and housework: Marriage, parenthood, and time on housework." Journal of Marriage and Family 70 (2008): 259-72. [CrossRef]

43. Nock, Steven L. "Commitment and dependency in marriage." Journal of Marriage and Family (1995): 503-14. [CrossRef]

44. Smock, Pamela J. "Cohabitation in the United States: An appraisal of research themes, findings, and implications." Annual Review of Sociology 26 (2000): 1-20. [CrossRef] 
45. Ono, Hiromi. “Women's economic standing, marriage timing, and cross-national contexts of gender." Journal of Marriage and Family 65 (2003): 275-86. [CrossRef]

46. Fuwa, Makiko, and Philip N. Cohen. "Housework and social policy." Social Science Research 36 (2007): 512-30. [CrossRef]

47. Esping-Andersen, Gøsta. The Three Worlds of Welfare Capitalism. Princeton: Princeton University Press, 1990.

48. Esping-Andersen, Gøsta. Social Foundations of Postindustrial Economies. New York: Oxford University Press, 1999.

49. O'Connor, Julia S., Ann S. Orloff, and Sheila Shaver. States, Markets, Families: Gender, Liberalism and Social Policy in Australia, Canada, Great Britain and the United States. Cambridge: Cambridge University Press, 1999.

50. Lichter, Daniel T., Deborah R. Graefe, and J. Brian Brown. "Is marriage a panacea? Union formation among economically disadvantaged unwed mothers." Social Problems 50 (2003): 60-86. [CrossRef]

51. Nock, Steven L. "Marriage as a public issue." The Future of Children 15 (2005): 13-32. [CrossRef] [PubMed]

52. Arts, Wil, and John Gelissen. "Three worlds of welfare capitalism or more? A state-of-the-art report." Journal of European Social Policy 12 (2002): 137-58. [CrossRef]

53. Ebbinghaus, Bernhard. "Comparing Welfare State Regimes: Are Typologies an Ideal or Realistic Strategy?" Paper presented at the ESPAnet Conference, Edinburgh, UK, 6-8 September 2012.

54. Schröder, Martin. "Integrating welfare and production typologies: How refinements of the varieties of capitalism approach call for a combination of welfare typologies." Journal of Social Policy 38 (2009): 19-43. [CrossRef]

55. Ferrera, Maurizio. "The 'Southern model' of welfare in social Europe." Journal of European Social Policy 6 (1996): 17-37. [CrossRef]

56. Inglehart, Ronal, and Pippa Norris. Rising Tide: Gender Equality and Cultural Change Around the World. Cambridge: Cambridge University Press, 2003.

57. Reher, David S. "Family ties in Western Europe: Persistent contrasts." Population and Development Review 24 (1998): 203-34. [CrossRef]

58. United Nations Development Program. Human Development Report. New York: Palgrave Macmillan, 2006.

59. Beck, Nathaniel, and Jonathan N. Katz. "What to do (and not to do) with time-series cross-section data." American Political Science Review 89 (1995): 634-47. [CrossRef]

60. Greene, William H. Econometric Analysis. London: Prentice-Hall International, 2000.

61. Ruud, Paul A. An Introduction to Classical Econometric Theory. New York: Oxford University Press, 2000.

62. Winkler-Dworak, Maria, and Henriette Engelhardt. "On the tempo and quantum of first marriages in Austria, Germany, and Switzerland: Changes in mean age and variance." Demographic Research 10 (2004): 231-64. [CrossRef]

63. Andersson, Gunnar. “Trends in marriage formation in Sweden 1971-1993." European Journal of Population/Revue européenne de Démographie 14 (1998): 157-78. [CrossRef] [PubMed]

(C) 2017 by the author; licensee MDPI, Basel, Switzerland. This article is an open access article distributed under the terms and conditions of the Creative Commons Attribution (CC-BY) license (http://creativecommons.org/licenses/by/4.0/). 